\title{
In situ ground radiometric survey and risk assessments of allanite-bearing beach sands in Erawan, Palawan
}

\author{
Reymar R. Diwa ${ }^{a}$, Edmundo P. Vargasa ${ }^{a}$, Estrellita U. Tabora ${ }^{a}$, Botvinnik L. Palattao ${ }^{a}$, \\ Rolando Y. Reyes ${ }^{\text {a }}$ Jennyvi D. Ramirez ** \\ ${ }^{a}$ Department of Science and Technology - Philippine Nuclear Research Institute (DOST-PNRI), \\ Commonwealth Ave., Diliman, Quezon City 1101, Philippines \\ *Corresponding Author: jpdayaon@pnri.dost.gov.ph
}

\section{HIGHLIGHTS}

- Elevated radioactivity and high risk indices attributed to Th in allanite

- High $\mathrm{K}$ and $\mathrm{U}$ contents potentially from phosphate fertilizer use in farms

- High human health risk associated with the radionuclides

- Radiological risk indices evaluate the safety of beach sands as building materials

\begin{abstract}
Past exploration for $U$ deposit in the Philippines discovered the mineralization of radioactive allanite in Palawan. The allanite occurs as sand component in the heavily populated beach of Erawan, San Vicente, Palawan. This work assessed the risks associated with the radionuclides in Erawan beach by in situ ground radiometric survey of $K, U$, and Th in 694 sampling points. Principal component analysis (PCA) and Pearson correlation coefficient were used to determine the similarity between the radionuclides and to identify other probable anthropogenic sources of radionuclides. Our results show that the mean activity concentrations of $K\left(597.8 \mathrm{~Bq} \mathrm{~kg}^{-1}\right)$ and Th $\left(93.15 \mathrm{~Bq} \mathrm{~kg}{ }^{-1}\right)$ are equivalent to 1.5 and 3.1 times of the world average natural radioactivity levels in soil, respectively, while the mean $U\left(34.7 \mathrm{~Bq} \mathrm{~kg}^{-1}\right)$ is similar to the world average. The mean radiological risk assessments like radium equivalent, gamma specific activity index, external hazard index, internal hazard index, absorbed gamma dose rate, annual effective dose equivalent, annual gonadal equivalent dose, and excess lifetime cancer risk are $213.96 \mathrm{~Bq} \mathrm{~kg}^{-1}, 0.78,0.58$, $0.67,97.24 n G y h^{-1}, 119.25 \mu S v y^{-1}, 684.39 \mu S v y^{-1}$, and $0.42\left(10^{-3}\right)$, respectively. Th consistently correlated most to the risks. We attribute the occurrence of Th to the presence of allanite, K to fertilizer use for farming, and $U$ to both the allanite and farming. The results of our study can provide important baseline data for future detailed studies or monitoring of the long-term effects of elevated radiation levels to the local population of Erawan.
\end{abstract}

Keywords: allanite, radiometric survey, radiological risk assessment, AEDE, AGED, ELCR 


\section{INTRODUCTION}

The construction of the Philippines' Bataan Nuclear Power Plant in 1970s led to a nationwide exploration for $U$. The close association of $U$ deposits with granitic bodies (Chen et al., 2012; Luo et al., 2017; Zhao et al., 2016) prompted several explorations in the only two known granitic bodies in the country found in San Vicente, Palawan. Bay Peak Pluton is one of the two granitic bodies that intruded the sedimentary and metamorphic rock Formations in Northern Palawan during the Middle Miocene (Encarnación, 2004; Suggate et al., 2014). It is classified as metaluminous, high-K calc-alkaline, I-type biotite granite consisting of plagioclase, quartz, K-feldspar, and biotite with inclusions of ilmenite, apatite, and zircon (Encarnación, 2004; Padrones et al., 2017). Numerous unpublished reports by the Philippine Atomic Energy Commission or PAEC (now PNRI) indicate U and Th anomalies specifically in Erawan beach in San Vicente because of allanite accumulation. Allanite is a common accessory mineral in igneous rocks that contains $U$ and $\mathrm{Th}$ (Hermann, 2002). Determination of $U$ and Th contents of the allanite in Erawan using ${ }^{241} \mathrm{Am}$-excited X-ray fluorescence indicated concentrations of $150 \pm 0.0056 \mathrm{ppm}$ and 11,873 $\pm 0.086 \mathrm{ppm}$, respectively (Dingle et al., 2019). Despite numerous studies conducted in Erawan and neighboring areas, it is still unproven whether the allanite originated from the granitic bodies.

The small scale agricultural and fishing industries led to the development of settlement along Erawan beach. Located in one of the most beautiful islands in the world, the beach also attracts many local and international tourists. The increased human activity in the area raised concern to the local population and the government over radiation exposure. Radiation exposure may occur by direct irradiation from rocks and soils, inhalation of radon gas daughter products and radioactive dust particles, and ingestion of radionuclides (Gulson et al., 2005). Exposure to high background ionizing radiation by ${ }^{40} \mathrm{~K},{ }^{232} \mathrm{Th}$, and ${ }^{238} \mathrm{U}$ can have adverse effects to human health. Long-term exposure to ionizing radiation can cause increased risk for developing cancer, cardiovascular disease, cognitive impairment, and other non-cancer diseases (Kamiya et al., 2015; Marazziti et al., 2012). It also has a dire effect to human DNA as it increases the mutation rates in the germline of parents exposed to radiation (Dubrova, 2003). Monitoring of radiation exposure therefore should be of crucial importance (Roscoe et al., 1995). In situ gamma ray spectrometry offers low-cost, rapid, and spatially-representative method for assessment of radioelement anomalies and radioactivity exposure (Kaniu et al., 2018).

This study aims to establish baseline information of ${ }^{40} \mathrm{~K},{ }^{232} \mathrm{U}$, and ${ }^{238} \mathrm{Th}$ activity concentrations in Erawan beach and assess the potential human health risks associated with these radionuclides through in situ ground radiometric survey using Bismuth Germanate Oxide (BGO) Handheld Spectrometer. A total of 694 data points covering the beach, residential area, and farmland in the study site were assessed. The results of the survey and the risk assessments were compared to the world average and local and international regulatory limits. Despite many studies detailing U and Th mineralization in Erawan, knowledge on the potential risks associated with these radionuclides that have direct consequence to the well-being of the local population are yet to be investigated. To address this critical knowledge gap, we not only assessed the risks but we also identified other radionuclide sources and correlated the degree of association of the risk indices with the radionuclide concentrations. To the best of the authors' knowledge, this is the first detailed risk assessment of the natural and anthropogenic sources of high background radiation in Erawan, San Vicente.

\section{METHODOLOGY}

\subsection{Study Area}

The study area is located at Erawan, San Vicente, Palawan and is bounded by latitudes 10.633 to 10.660 and longitudes 119.326 to 119.343 . Farming and fishing are the main economic activity in the area leading to concentration of population along the allanite-bearing beach. 
Figure 1 shows the location map of data points, land use pattern, and geology of the study area. Situated on the coast of Northern Palawan, the study area is flat-lying and is bounded by steep promontory consisting of granodiorites of the Bay Peak Pluton in the north. Bay Peak Pluton is one of the two Middle Miocene intrusive bodies in Northern Palawan (Encarnación \& Mukasa, 1997; Suggate et al., 2014). It is classified as metaluminous, high-K calc-alkaline, I-type biotite granite consisting of plagioclase, quartz, K-feldspar, and biotite with inclusions of ilmenite, apatite, and zircon (Encarnación \& Mukasa, 1997; Padrones et al., 2017). The flat area consists mostly of quaternary alluvium with reported semi-schists of the Tumarbong semi-schists. Tumarbong semi-schist is a member of the Concepcion Phyllite that underwent low degree metamorphism. Due to absence of schist outcrops during the fieldwork we used the map of Forster et al., (2015) to delineate the schist from the alluvium.

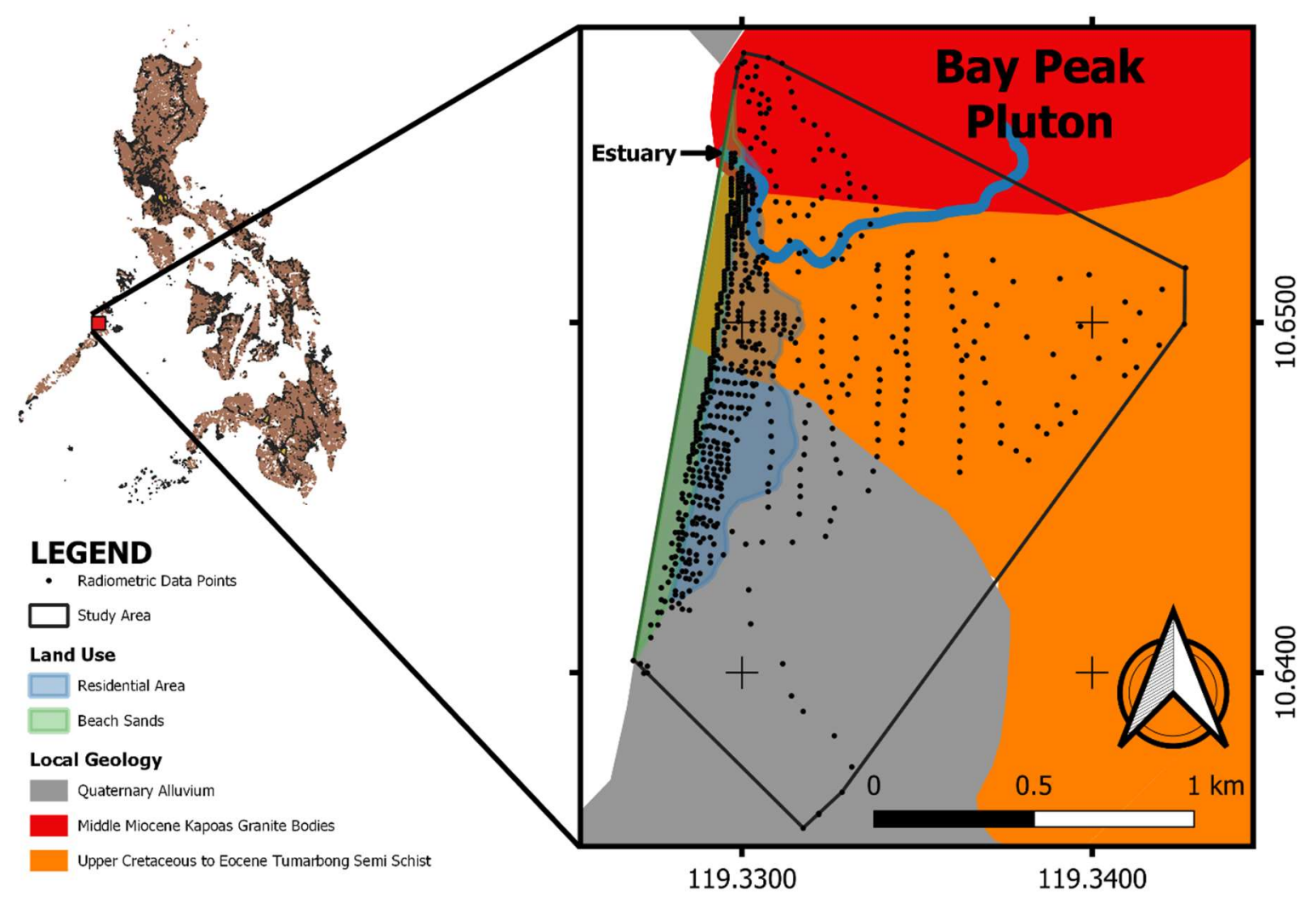

Figure 1. The combined radiometric data points, land use, and geologic maps of Erawan showing the Bay Peak (modified from Forster et al., 2015). The geology of the study area consists of the Bay Peak Pluton, Tumarbong Semischist, and Quaternary Alluvium. The river traversing the study site is highlighted by the blue line.

\subsection{In situ surface radiometric survey}

In situ radiometric survey of Potassium (K), Uranium (U), and Thorium (Th) of the study area was conducted by walking using RS 230 Bismuth Germanate Oxide (BGO) Handheld Spectrometer (Radiation Solutions, Canada) equipped with $103 \mathrm{~cm}^{3}$ (BGO) detector. This spectrometer resolves the natural gamma ray spectrum over the range of $30 \mathrm{keV}$ to $3000 \mathrm{keV}$ into 1024 channels. The reliability of the spectrometer was pre-validated using a set of Grasty Pads, which are $1 \mathrm{~m} \times 1 \mathrm{~m} \times 30 \mathrm{~cm}$ concrete standard calibration pads: one background pad and three pads salted with known concentrations of radioelements ${ }^{40} \mathrm{~K},{ }^{238} \mathrm{U}$, and ${ }^{232} \mathrm{Th}$, prior to field measurements. Three (3) readings using Assay mode were collected for each data point with a reading time of $120 \mathrm{~s}$ above the surface. A total of 694 data points were collected from Erawan beach and the surrounding area. Calculated mean values for each data point were reported. 


\subsection{Risk Assessments}

The occurrence of radionuclides in the sands constitutes a direct route for human exposure (Nieder et al., 2018). Depending on the concentration of the radionuclides, ionizing radiation can be biologically harmful. Ionizing radiation can cause cancer and mutations and prodromal symptoms such as anorexia, nausea, vomiting, diarrhea, nervousness, confusion, and consciousness in humans (Sharma et al., 2010). To assess the risks associated with the presence of radionuclides in the sands, we calculated several risk indices with indirect or direct consequence to human health such as Radium Equivalent $\left(\mathrm{Ra}_{\mathrm{eq}}\right)$, Gamma Specific Activity Index $\left(\mathrm{I}_{\gamma}\right)$, External hazard index $\left(\mathrm{H}_{\mathrm{ex}}\right)$, Internal hazard index $\left(\mathrm{H}_{\mathrm{in}}\right)$, Absorbed Gamma Dose Rate $\left(\mathrm{D}_{\mathrm{air}}\right)$, Annual Effective Dose Equivalent (AEDE), Annual Gonadal Equivalent Dose (AGED), and Excess Lifetime Cancer Risk (ELCR).

\subsection{Statistical Analysis}

To determine the relationship between the radionuclides and the associated risks, we performed multivariate analysis such as principal component analysis (PCA) and Pearson correlation coefficient $(r)$. PCA identifies new variables called the principal components which are linear combinations of and reduced from the original variables without significant loss of information (Ringnér, 2008). Pearson correlation gives the degree of strength of linear correlation between two variables. The factor loadings of the activity concentrations of the radionuclides and radionuclide contribution of the principal components were calculated using the PCA syntax of $\mathrm{R}$ ver. 4.0.4. The heatmap of Pearson correlation coefficient was performed using the cor syntax of the corrplot package.

\subsection{Spatial mapping}

To delineate the radionuclide activity concentrations and the risk assessments, spatial interpolation was done using the Natural Neighbor method of Surfer ${ }^{\circledR}$ 11.1.719. Natural Neighbor interpolation is suitable for the data due to the irregularity of spacing of the data points (Boissonnat \& Cazals, 2002; Sambridge et al., 1995). The color-coding scheme of the activity concentrations of the radionuclides is based on the world average natural radioactivity in soil. Meanwhile, the color-coding scheme for the calculated risk assessments is based on the world average and local and international regulatory limits.

\section{RESULTS AND DISCUSSION}

\subsection{Radiometric Anomalies and Source Identification}

The survey determined the activity concentrations of K, U, and Th in 694 points in the study site (Figure 1). The statistics of the activity concentrations of the radionuclides is presented in Table 1. The mean (range) activity concentrations of K, U, and Th are 597.8 (125.2-1430.4), 34.7 (6.2-151.9), 93.15 (5.281014.19) $\mathrm{Bq} \mathrm{kg}^{-1}$. The mean $\mathrm{K}$ and $\mathrm{Th}$ are equivalent to 1.5 and 3.1 times of the world average natural radioactivity levels in soil while the mean $\mathrm{U}$ is similar to the world average. It is worth mentioning that the upper range of the $\mathrm{K}, \mathrm{U}$, Th activity concentrations are equivalent to 3.6, 4.3, and 33.8 times of the world average concentrations in soil, respectively.

Table 1. Summary statistics of activity concentrations of ${ }^{40} \mathrm{~K},{ }^{232} \mathrm{Th}$, and ${ }^{238} \mathrm{U}$ of

\begin{tabular}{cccc}
\multicolumn{4}{c}{ Erawan beach and the surrounding areas. } \\
\hline $\boldsymbol{n}$ & $\mathbf{K ~ ( B q / \mathbf { k g } )}$ & $\mathbf{U}(\mathbf{B q} / \mathbf{k g})$ & $\mathbf{T h}(\mathbf{B q} / \mathbf{k g})$ \\
\hline Mean & 694 & 694 & 694 \\
SD & 598.0 & 34.8 & 93.18 \\
& 188.8 & 18.4 & 141.46 \\
\hline
\end{tabular}




\begin{tabular}{cccc}
\hline Median & 532.1 & 30.3 & 47.10 \\
Minimum & 125.2 & 6.2 & 5.28 \\
Maximum & 1430.4 & 151.9 & 1014.19 \\
$\begin{array}{c}\text { World } \\
\text { Average* }\end{array}$ & 400 & 35 & 30 \\
*UNSCEAR (2000) & & &
\end{tabular}

Figures 2A-C show the spatial variation of the radionuclides. The highest $U$ and $T h$ activity concentrations were measured in the mouth of the river. These anomalous activities are attributed to the abundance of allanite. The river carries the allanite and deposits them to the shore and with further wave action, the allanite grains are deposited to the beach as placer. We also found high activity concentrations of $\mathrm{K}$ and $\mathrm{U}$ in the surrounding farmlands. These values are most likely unnatural and under influence by heavy use of fertilizers for farming. In general, the residential areas have the lowest measured radionuclide concentrations apart from those proximal to the river. The measured concentrations may be affected by the structures made of concrete that prevents the instrument from receiving more signals due to shielding effect by concrete (Kaplan, 1989).

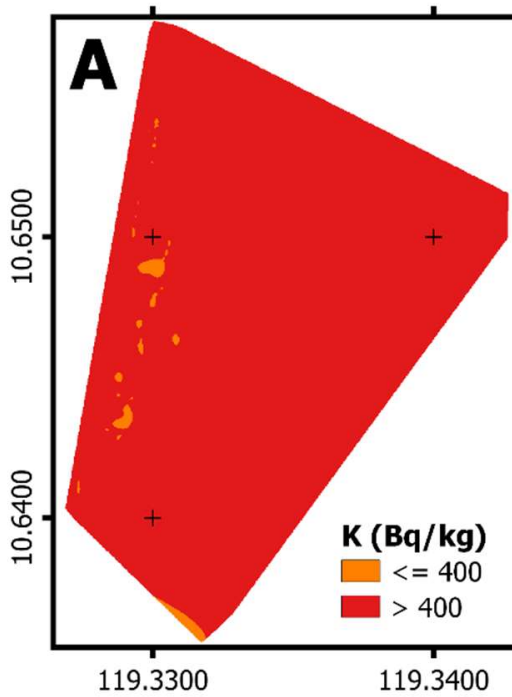

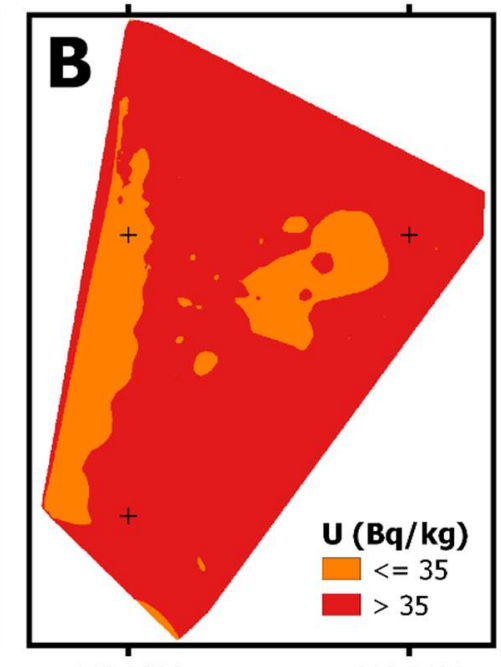

119.3300

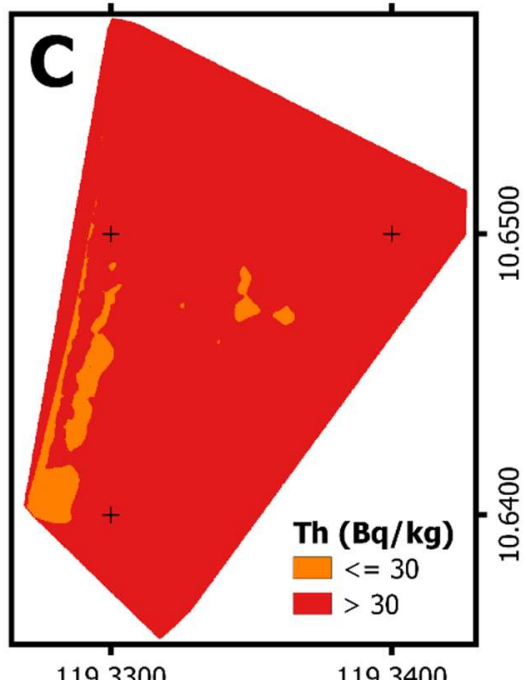

119.3300

119.3400

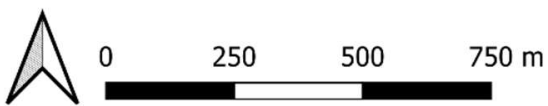

Figure 2. Activity concentration $\left(\mathrm{Bq} \mathrm{kg}{ }^{-1}\right)$ maps of ${ }^{40} \mathrm{~K},{ }^{232} \mathrm{Th}$, and ${ }^{238} \mathrm{U}$ in Erawan beach and the surrounding areas. The color coding is based on the world average natural radioactivity in soils. The river mouth, areas proximal to it, farmlands, and some parts of the residential area have above average radionuclide concentrations.

While it is apparent that the source of the radionuclides (particularly Th) is of natural origin, it is still important to identify other probable natural and anthropogenic sources. The spatial distribution of the allanite (i.e., high concentration in the river mouth) observed during the fieldwork could not explain the high $U$ activity concentrations found inland, especially in the farmlands. We performed principal component analysis (PCA) and Pearson correlation analysis to show the similarity in sources of the radionuclides. Multivariate analyses like the PCA and Pearson correlation are useful to discriminate the 
various sources of metals in the natural environment by grouping them according to their similarities (Buttafuoco et al., 2010; Guagliardi et al., 2012).

Three (3) principal components were identified by the PCA, two of which have eigenvalues greater than $1.0 \%$ and explain $94.3 \%$ of the total variance in the dataset. The radionuclide contribution of the first two principal components is shown in Figure 3A. PC1 explains $56.1 \%$ of the variance and contributes mostly $\mathrm{U}(53.1 \%)$ and Th (44.3\%) which can be attributed to the allanite. Meanwhile, PC2 explains $38.3 \%$ of the variance and contributes K (80.6\%) associated with widespread use of fertilizer for farming (Heckman \& Kamprath, 1992). The Pearson correlation coefficient further differentiates the sources of $U$ and Th. We found low correlation coefficients $(r-0.19$ to 0.67$)$ among the individual radionuclides (Figure 3B) suggesting unique or mixed sources. Despite the occurrence of minor concentration of $U$ with the Th in the allanite, U can also be sourced anthropogenically from phosphate fertilizer use (Schipper et al., 2011; Y Sun et al., 2020; Yajie Sun et al., 2020; Takeda et al., 2006; Palattao et al., 2018). This could potentially explain the occurrence of $\mathrm{U}$ in the farmlands and the low correlation coefficient between $\mathrm{U}$ and Th $(r$ 0.67). Previous estimates of $U$ and $T h$ concentrations in the allanite using ${ }^{241} \mathrm{Am}$-excited X-ray fluorescence shows the occurrence of Th as a major element at $11,873 \pm 0.086 \mathrm{ppm}$ and $\mathrm{U}$ as a minor element at $150 \pm 0.0056$ ppm (Dingle et al., 2019).
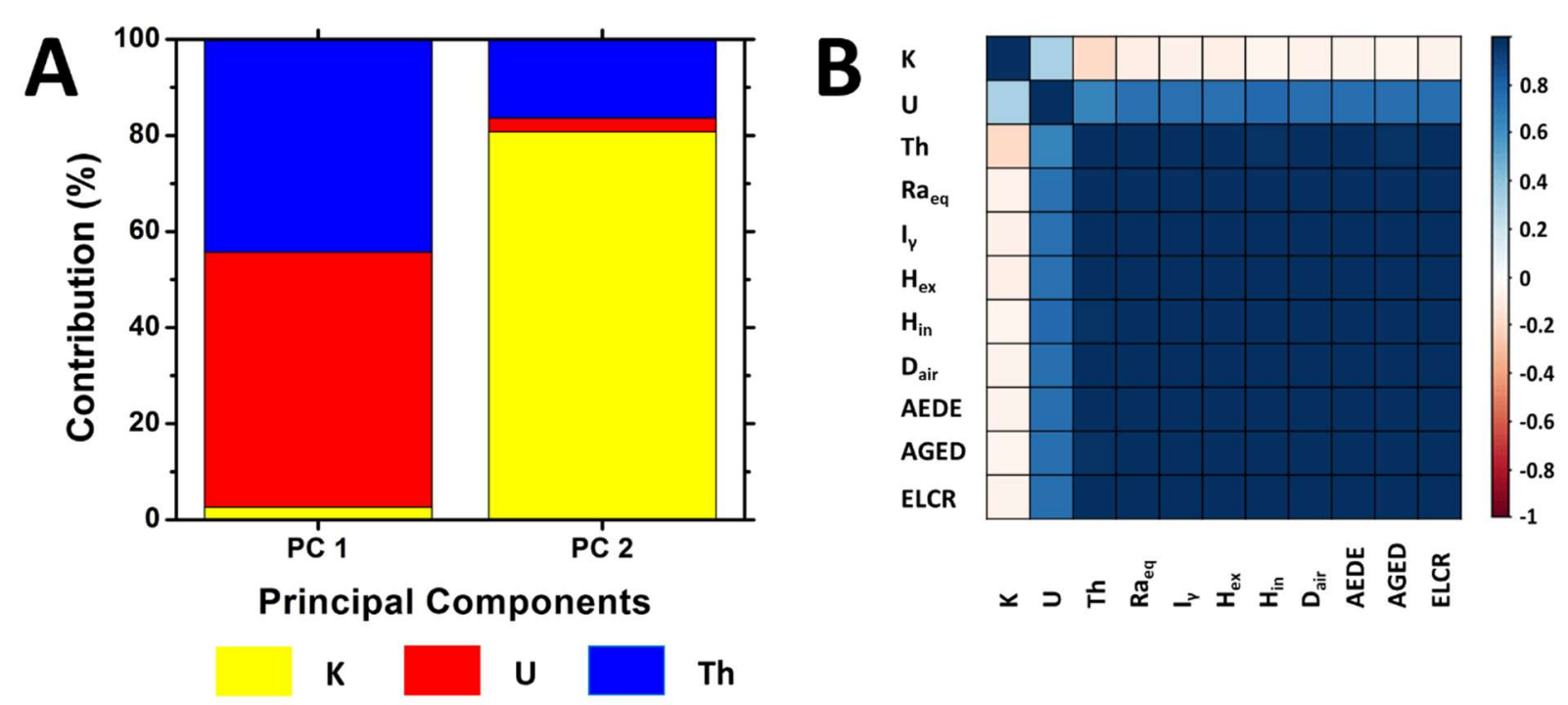

Figure 3. (A) The radionuclide contribution of the two primary principal components identified by the PCA shows that the PC 1 contributes mainly $\mathrm{U}$ and Th from the allanite and PC 2 contributes mostly $\mathrm{K}$ from fertilizer use. (B) Pearson correlation matrix of the activity concentrations of $\mathrm{K}, \mathrm{U}$, Th and the risk indices shows that the radionuclides have low correlation with one another and that the risk indices are mostly associated to Th.

\subsection{Risk Assessments}

The sands are being used as construction materials by the local community. Depending on many factors such as the concentration of the radionuclides, amount of time spent outside by an individual, etc., there is potential consequence to human health by radiation exposure. We used a total of 8 radiological risk indices to assess the safety of using the sands for the construction of dwellings and to quantify the potential health effects of the elevated radiation to the local population.

\subsubsection{Radium Equivalent}

The allanite-bearing sand is used by the locals as material for the construction of dwellings. A decay product of the fission of ${ }^{238} \mathrm{U}$ and ${ }^{232} \mathrm{Th},{ }^{222} \mathrm{Rn}$ is a dense radioactive noble gas which is the dominant household 
source of ionizing radiation in most countries (Little, 1997). Unlike other decay products, ${ }^{222} \mathrm{Rn}$ is mobile and migrates through the cracks in concrete which can easily be inhaled by inhabitants and is therefore a major health hazard (Dimbylow \& Wilkinson, 1985). The radiological hazards associated with the use of radionuclide-containing materials for construction can be evaluated by radium equivalent $\left(\mathrm{Ra}_{\mathrm{eq}}\right)$ using the activity concentrations of ${ }^{40} \mathrm{~K},{ }^{238} \mathrm{U}$, and ${ }^{232} \mathrm{Th}$. $\mathrm{Ra}_{\mathrm{eq}}$ assumes that $1 \mathrm{~Bq} \mathrm{~kg}^{-1}$ of ${ }^{238} \mathrm{U}, 0.7 \mathrm{~Bq} \mathrm{~kg}^{-1}$ of ${ }^{232} \mathrm{Th}$, and $13 \mathrm{~Bq} \mathrm{~kg}^{-1}$ of ${ }^{40} \mathrm{~K}$ produce the same gamma dose rate according to Equation 1:

$$
\mathrm{Ra}_{\mathrm{eq}}\left(\mathrm{Bq} \mathrm{kg}^{-1}\right)=\mathrm{A}_{\mathrm{U}}+1.43 \mathrm{~A}_{\mathrm{Th}}+0.077 \mathrm{~A}_{\mathrm{K}}<370 \quad \text { (Equation 1) }
$$

where $A_{U}, A_{T h}$, and $A_{K}$ are the activity concentrations of ${ }^{238} U,{ }^{232} \mathrm{Th}$, and ${ }^{40} \mathrm{~K}$, respectively. The maximum value of $\mathrm{Ra}_{\mathrm{eq}}$ must be less than the safe value of $370 \mathrm{~Bq} \mathrm{~kg}^{-1}$ which is equivalent to the permissible annual dose rate of $1 \mathrm{mSv}^{-1}$ for the general public (Júnior et al., 2010). The $\mathrm{Ra}_{\mathrm{eq}}$ of the study area range from 41.47 to $1591.60 \mathrm{~Bq} \mathrm{~kg}^{-1}$ with a mean of $213.96 \mathrm{~Bq} \mathrm{~kg}^{-1}$ which is less than the $370 \mathrm{~Bq} \mathrm{~kg}^{-1}$ limit. The area around the river mouth exceeded the limit as shown in Figure 4A. This is due to allanite accumulation in the river mouth.

\subsubsection{Gamma Specific Activity Index}

The radionuclides emit gamma radiation which can be a health hazard. To further assess the potential hazards caused by using the sands as construction materials, we calculated the Gamma Specific Activity Index $\left(\mathrm{I}_{\gamma}\right)$ which examines whether a construction material meets the regulatory limit of dose criteria $(0.3$ to $1 \mathrm{mSv} \mathrm{y}^{-1}$ ) for gamma radiation (Abdel-Rahman et al., 2021). $\mathrm{I}_{\gamma}$ is calculated using Equation 2.

$$
\mathrm{I}_{\gamma}=\frac{A_{\mathrm{U}}}{300}+\frac{A_{\mathrm{Th}}}{200}+\frac{A_{\mathrm{K}}}{3000} \quad(\text { Equation } 2)
$$

Values of $\mathrm{I}_{\gamma} \leq 2$ corresponds to annual dose rate of $0.3 \mathrm{mSv}^{-1}$ and $\mathrm{I}_{\gamma} \leq 6$ corresponds to $1 \mathrm{mSv}^{-1}$. Values of $\mathrm{I}_{\gamma} \geq 6$ corresponds to an annual dose rate exceeding the regulatory limit which is considered unsafe for the population. Our findings show that $\mathrm{I}_{\gamma}$ of the study area range from 0.17 to 5.57 with a mean of 0.78 . These values are all within the safe limit for gamma radiation. The spatial variation of $\mathrm{I}_{\gamma}$ of the study area is shown in Figure 4B.

\subsubsection{External and Internal Hazard Indices}

Estimation of gamma radiation exposure of an individual from external sources is possible using the external hazard index $\left(\mathrm{H}_{\mathrm{ex}}\right)$ which uses the activity concentrations of the radionuclides and the average time spent outdoors. Meanwhile, quantification of radiation exposure from radon and its daughter products via inhalation and ingestion is possible using the internal hazard index $\left(\mathrm{H}_{\mathrm{in}}\right) . \mathrm{H}_{\mathrm{ex}}$ and $\mathrm{H}_{\mathrm{in}}$ are calculated using Equations 3 and 4, respectively (Lu et al., 2014).

$$
\begin{aligned}
& H_{e x}=\frac{A_{U}}{370}+\frac{A_{T h}}{259}+\frac{A_{K}}{4810} \leq 1 \quad \text { (Equation 3) } \\
& H_{\text {in }}=\frac{A_{U}}{185}+\frac{A_{T h}}{259}+\frac{A_{K}}{4810} \leq 1 \quad \text { (Equation 4) }
\end{aligned}
$$

If the maximum concentration of uranium is half that of the normal acceptable limit, then $\mathrm{H}_{\mathrm{ex}}$ and $\mathrm{H}_{\mathrm{in}}$ are less than 1. For a safe utilization of the sands as construction materials, $\mathrm{H}_{\mathrm{ex}}$ and $\mathrm{H}_{\text {in }}$ should be less than the unity to reduce the external dose rate to $1.5 \mathrm{mGy} \mathrm{y}^{-1}$ (Ghias et al., 2021). The mean $\mathrm{H}_{\mathrm{ex}}$ and $\mathrm{H}_{\text {in }}$ of the study area are 0.58 and 0.67 , respectively. These are within the permissible safe limit of $\leq 1$ (UNSCEAR, 2000). Although the range of values of $\mathrm{H}_{\mathrm{ex}}$ and $\mathrm{H}_{\text {in }}$ are 0.11 - 4.30 and $0.13-4.60$, respectively, indicating some areas, particularly the river mouth, exceed the safe limit as shown in Figure 4C-D. 

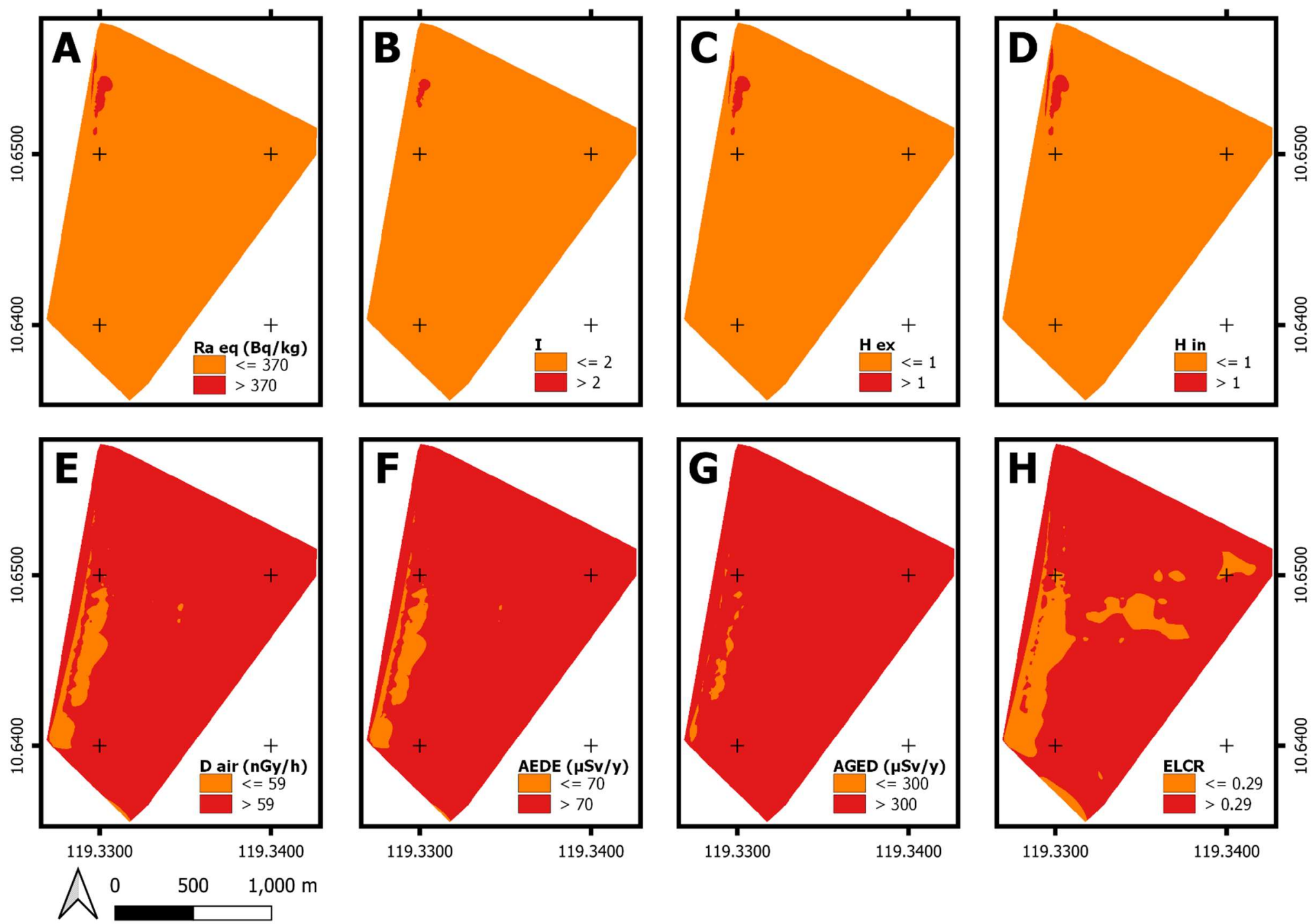

Figure 4. Radiological hazard assessment of Erawan beach and the surrounding areas 


\subsubsection{Absorbed Gamma Dose Rate}

The absorbed gamma dose rate $\left(\mathrm{D}_{\text {air }}\right)$ or simply, dose rate, is the measure of the radiation dose intensity from natural radionuclides in the open air at 1 meter above the ground. It can indirectly measure the impact of gamma radiation from ambient radioactive sources to human health. It is the amount of radiation from $\mathrm{K}$, $\mathrm{U}$, and $\mathrm{Th}$ expected to be received by a person at a given time and is directly proportional to the concentration of the radionuclides according to Equation 5 (Ramasamy et al., 2013).

$$
D\left(n G y h^{-1}\right)=0.462 A_{U}+0.604 A_{T h}+0.0417 A_{K} \quad \text { (Equation 5) }
$$

The $\mathrm{D}_{\text {air }}$ of the study area range from 20.97 to $680.15 \mathrm{nGy} \mathrm{h}^{-1}$ with a mean of $97.24 \mathrm{nGy} \mathrm{h}^{-1}$ (UNSCEAR, 2000). The mean exceeds the world average $\mathrm{D}_{\text {air }}$ of $59 \mathrm{nGy} \mathrm{h}^{-1}$. The river mouth, beach, and farmlands have the highest $D_{\text {air }}$ as shown in Figure 4E. The $D_{\text {air }}$ in residential areas is below the world average $D_{\text {air }}$.

\subsubsection{Annual Effective Dose Equivalent}

The annual effective dose estimate (AEDE) is the estimated effective radiation dose received by a person in a year and is directly proportional to the dose rate $\left(\mathrm{D}_{\text {air }}\right)$. The AEDE of the population can be calculated using Equation 6,

$$
A E D E\left(S v h^{-1}\right)=D\left(n G y h^{-1}\right) \times 8760 h \times 0.2 \times 0.7 S v G y^{-1} \times 10^{-3} \text { (Equation 6) }
$$

where $\mathrm{D}$ is the dose rate $\left(\mathrm{D}_{\text {air }}\right), 8760 \mathrm{~h}$ is the number of hours in a year, 0.2 is the outdoor occupancy factor, and 0.7 is the quotient of annual effective dose received by adults to dose rates (Kaniu et al., 2018). The mean AEDE is $119.25 \mu \mathrm{Sv} \mathrm{y}^{-1}$ which exceeds the world average AEDE of $70 \mu \mathrm{Sv} \mathrm{y}^{-1}$ (UNSCEAR, 2000). The AEDE of the study area range from 25.72 to $834.14 \mu \mathrm{Sv} \mathrm{y}^{-1}$ depending on the proximity to the river mouth, farmlands, and the beach as shown in Figure 4F. Areas proximal to the river mouth has the highest AEDE which is $12 x$ the world average. The allanite concentrates on the estuary after being carried by the river and eventually washes away by the water to the sea during the rain.

\subsubsection{Annual Gonadal Equivalent Dose}

It is an established fact that exposure to high dose of radiation can have deleterious effects to human health, including cancer. High levels of ionizing radiation can have genetic and somatic effects which can become hereditary (UNSCEAR, 1986). The gonads, active bone marrow, and bone surface cells are the main body organs of concern for assessment of radiation exposure (UNSCEAR, 2000). In this study, we assessed the exposure of gonads to ionizing radiation using the annual gonadal equivalent dose (AGED) given by Equation 7 (Ramasamy et al., 2013).

$$
A G E D\left(m S v y^{-1}\right)=3.09 A_{U}+4.18 A_{T h}+0.314 A_{K} \quad \text { (Equation 7) }
$$

The calculated AGED range from 153.07 to $4704.51 \mu \mathrm{Sv} \mathrm{y}^{-1}$ with a mean of $684.39 \mu \mathrm{Sv} \mathrm{y}^{-1}$. The mean AGED exceeds the world average AGED of $300 \mu \mathrm{Sv} \mathrm{y}^{-1}$ (UNSCEAR, 2000). The maximum AGED in the study area is in the river mouth. All the areas, except some parts of the residential area, have AGED values exceeding the world average as shown in Figure 4G.

\subsubsection{Excess Lifetime Cancer Risk}

We also estimate the probability of cancer development over an individual lifetime. Excess lifetime cancer risk (ELCR) quantifies the likelihood of developing cancer due to long-term exposure to ionizing radiation. It is calculated using Equation 8,

$$
E L C R=A E D E \times D L \times R F \quad(\text { Equation } 8)
$$


where AEDE is the annual effect dose equivalent, DL is the lifetime duration of 70 years, and RF is the risk factor of 0.05 for the general public (ICRP, 1990; Taskin et al., 2009). The ELCR vary from $0.09\left(10^{-3}\right)$ to $2.92\left(10^{-3}\right)$ with a mean of $0.42\left(10^{-3}\right)$. The mean significantly exceeds the world average ELCR in soil of $0.29\left(10^{-3}\right)$ (UNSCEAR, 2000). Like the other risk indices, the ELCR of the river mouth, beach, and the farmlands exceed the world average as shown in Figure 4H. Some areas of the residential have ELCR less than the world average.

\subsection{Relationship of the radionuclides and the risk indices}

We also used the Pearson correlation coefficient to determine the degree of relationship between the radionuclides and the risk indices as shown in Figure 3B. In the absence of quantified contribution by the natural and anthropogenic sources of radionuclides in the study area, we determined the degree of association of the risks with the radionuclides. We found that $\mathrm{K}$ is negatively correlated to all the risk indices $(r-0.05$ to -0.09$)$. $U$ has strong correlation with all the risk indices ( $r 0.74$ to 0.78$)$. Lastly, Th has very strong correlation with all the risk indices ( $r 0.99)$.

\section{CONCLUSIONS}

In situ ground radiometric survey showed that the mean activity concentrations of $\mathrm{K}$ and $\mathrm{Th}$ in the beach in Erawan, Palawan are several times higher than the world mean concentrations in soils while $\mathrm{U}$ is similar to the world average. Th is attributed to the occurrence of allanite in the beach sands, $\mathrm{K}$ is to fertilizer use for farming, and $U$ to both the allanite and fertilizer use. The mouth of the river traversing the study site consistently have the highest risks associated with the radionuclides. This is because of the prevalence of the allanite being carried by the river towards the shore. The mean of risk assessments like the mean $\mathrm{Ra}_{\mathrm{eq}}$, $\mathrm{I}_{\gamma}, \mathrm{H}_{\mathrm{ex}}$, and $\mathrm{H}_{\mathrm{in}}$ are in accordance with the international safe reference values. Although the other risk indices associated to human health such as the $\mathrm{D}_{\text {air }}$ AEDE, AGED, and ELCR exceed the safe limits or the world average values which suggests human health hazard in the long term. It is significant to note that the risks become more extreme to areas proximal to the river mouth. Of the three radionuclides analyzed, Th from the allanite consistently have the highest correlation to the risks.

The elevated radioactivity in Erawan beach is a result of combined natural and anthropogenic sources. There is no serious hazard on using the sands as construction materials except for the sands from the river mouth. Long-term human exposure to the sands can theoretically cause serious health problems. Since this study is limited to background radiation levels, we recommend conducting a detailed study on the health effects to the local populace. This includes review of mortality and morbidity statistics and conduct of more challenging epidemiological studies.

\section{ACKNOWLEDGEMENT}

This work was financially supported by the Department of Science and Technology (DOST) - Philippine Council for Industry, Energy and Emerging Technology Research and Development (PCIEERD). We are thankful to the provincial and local governments of Palawan for their invaluable support that greatly assisted this project and to the International Atomic Energy Agency (IAEA) for providing us the Grasty calibration pads.

\section{REFERENCES}

Abdel-Rahman, M. A. E., Sabry, M., Khattab, M. R., El-Taher, A., \& El-Mongy, S. A., 2021. Radioactivity and Risk Assessment with Uncertainty Treatment for Analysis of Black Sand Minerals. Zeitschrift 
Für Anorganische Und Allgemeine Chemie, 647(4), 210-217. https://doi.org/https://doi.org/10.1002/zaac.202000176

Boissonnat, J.-D., \& Cazals, F., 2002. Smooth surface reconstruction via natural neighbour interpolation of distance functions. Computational Geometry, 22(1), 185-203. https://doi.org/https://doi.org/10.1016/S0925-7721(01)00048-7

Buttafuoco, G., Tallarico, A., Falcone, G., \& Guagliardi, I., 2010. A geostatistical approach for mapping and uncertainty assessment of geogenic radon gas in soil in an area of southern Italy. Environmental Earth Sciences, 61(3), 491-505. https://doi.org/10.1007/s12665-009-0360-6

Chen, Y.-W., Bi, X.-W., Hu, R.-Z., \& Dong, S.-H., 2012. Element geochemistry, mineralogy, geochronology and zircon Hf isotope of the Luxi and Xiazhuang granites in Guangdong province, China: Implications for $\mathrm{U}$ mineralization. Lithos, 150, 119-134. https://doi.org/https://doi.org/10.1016/j.lithos.2012.06.025

Dimbylow, P. J., \& Wilkinson, P., 1985. The Numerical Solution of the Diffusion Equation Describing the Flow of Radon Through Cracks in a Concrete Slab. Radiation Protection Dosimetry, 11(4), 229236. https://doi.org/10.1093/oxfordjournals.rpd.a079471

Dingle, C. A. M., Jecong, J. F. M., Hila, F. C., Ramo, M. E. S. V, Guillermo, N. R. D., Vasquez Jr, M. R., \& Samson, V. A. I., 2019. Determination of the REE content, geological age, and absorbed alpha dose of allanite mineral from Palawan, Philippines. X-Ray Spectrometry, 48(5), 513-521. https://doi.org/https://doi.org/10.1002/xrs.3029

Dubrova, Y. E., 2003. Long-term genetic effects of radiation exposure. Mutation Research/Reviews in Mutation Research, 544(2), 433-439. https://doi.org/https://doi.org/10.1016/j.mrrev.2003.05.003

Encarnación, J., 2004. Multiple ophiolite generation preserved in the northern Philippines and the growth of an island arc complex. Tectonophysics, 392(1-4), 103-130. https://doi.org/10.1016/j.tecto.2004.04.010

Encarnación, J., \& Mukasa, S. B., 1997. Age and geochemistry of an 'anorogenic' crustal melt and implications for I-type granite petrogenesis. Lithos, 42(1), 1-13. https://doi.org/https://doi.org/10.1016/S0024-4937(97)00026-1

Forster, M. A., Armstrong, R., Kohn, B., Lister, G. S., Cottam, M. A., \& Suggate, S., 2015. Highly retentive core domains in K-feldspar and their implications for 40Ar/39Ar thermochronology illustrated by determining the cooling curve for the Capoas Granite, Palawan, The Philippines. Australian Journal of Earth Sciences, 62(7), 883-902. https://doi.org/10.1080/08120099.2015.1114524

Ghias, S., Satti, K. H., Khan, M., Dilband, M., Naseem, A., Jabbar, A., Kali, S., Ur-Rehman, T., Nawab, J., Aqeel, M., Khan, M. A., \& Zafar, M. I., 2021. Health risk assessment of radioactive footprints of the urban soils in the residents of Dera Ghazi Khan, Pakistan. Chemosphere, 267, 129171. https://doi.org/https://doi.org/10.1016/j.chemosphere.2020.129171

Guagliardi, I., Cicchella, D., \& De Rosa, R., 2012. A Geostatistical Approach to Assess Concentration and Spatial Distribution of Heavy Metals in Urban Soils. Water, Air, \& Soil Pollution, 223(9), 59835998. https://doi.org/10.1007/s11270-012-1333-z

Gulson, B. L., Mizon, K. J., Dickson, B. L., \& Korsch, M. J., 2005. The effect of exposure to employees from mining and milling operations in a uranium mine on lead isotopes - a pilot study. Science of The Total Environment, 339(1), 267-272. https://doi.org/https://doi.org/10.1016/j.scitotenv.2004.11.006

Heckman, J. R., \& Kamprath, E. J., 1992. Potassium Accumulation and Corn Yield Related to Potassium 
Fertilizer Rate and Placement. Soil Science Society of America Journal, 56(1), 141-148. https://doi.org/https://doi.org/10.2136/sssaj1992.03615995005600010022x

Hermann, J., 2002. Allanite: thorium and light rare earth element carrier in subducted crust. Chemical Geology, 192(3), 289-306. https://doi.org/https://doi.org/10.1016/S0009-2541(02)00222-X

[ICRP] International Commission on Radiological Protection, 1990. Recommendations of the International Commission on Radiological Protection. 21(1-3), publication 60.

Júnior, J. A. S., Amaral, R. S., Silva, C. M., \& Menezes, R. S. C., 2010. Radium equivalent and annual effective dose from geological samples from Pedra - Pernambuco - Brazil. Radiation Measurements, 45(7), 861-864. https://doi.org/https://doi.org/10.1016/j.radmeas.2010.03.011

Kamiya, K., Ozasa, K., Akiba, S., Niwa, O., Kodama, K., Takamura, N., Zaharieva, E. K., Kimura, Y., \& Wakeford, R., 2015. Long-term effects of radiation exposure on health. The Lancet, 386(9992), 469478. https://doi.org/https://doi.org/10.1016/S0140-6736(15)61167-9

Kaniu, M. I., Angeyo, H. K., Darby, I. G., \& Muia, L. M., 2018. Rapid in-situ radiometric assessment of the Mrima-Kiruku high background radiation anomaly complex of Kenya. Journal of Environmental Radioactivity, 188, 47-57. https://doi.org/https://doi.org/10.1016/j.jenvrad.2017.10.014

Kaplan, M. F., 1989. Concrete radiation shielding. John Wiley and Sons Inc.

Little, J. B., 1997. What are the risks of low-level exposure to $\alpha$ radiation from radon? Proceedings of the National Academy of Sciences, 94(12), 5996 LP - 5997. https://doi.org/10.1073/pnas.94.12.5996

Lu, X., Chao, S., \& Yang, F., 2014. Determination of natural radioactivity and associated radiation hazard in building materials used in Weinan, China. Radiation Physics and Chemistry, 99, 62-67. https://doi.org/https://doi.org/10.1016/j.radphyschem.2014.02.021

Luo, J.-C., Hu, R.-Z., Fayek, M., Bi, X.-W., Shi, S.-H., \& Chen, Y.-W., 2017. Newly discovered uranium mineralization at $\sim 2.0 \mathrm{Ma}$ in the Menggongjie granite-hosted uranium deposit, South China. Journal of Asian Earth Sciences, 137, 241-249. https://doi.org/https://doi.org/10.1016/j.jseaes.2017.01.021

Marazziti, D., Baroni, S., Catena-Dell’Osso, M., Schiavi, E., Ceresoli, D., Conversano, C., Dell'Osso, L., \& Picano, E., 2012. Cognitive, Psychological and Psychiatric Effects of Ionizing Radiation Exposure. Current Medicinal Chemistry, 19(12), 1864-1869. https://doi.org/10.2174/092986712800099776

Nieder, R., Benbi, D. K., \& Reichl, F. X., 2018. Health Risks Associated with Radionuclides in Soil Materials. In Soil Components and Human Health (pp. 451-501). Springer Netherlands. https://doi.org/10.1007/978-94-024-1222-2_9

Padrones, J. T., Imai, A., \& Takahashi, R., 2017. Geochemical Behavior of Rare Earth Elements in Weathered Granitic Rocks in Northern Palawan, Philippines. Resource Geology, 67(3), 231-253. https://doi.org/https://doi.org/10.1111/rge.12123

Palattao, B.L., Ramirez, J.D., Tabora, E.U., Marcelo, E.A., Vargas, E.P., Intoy, S.P., Diwa, R.R., Reyes, R.Y., 2018. Recovery of uranium from Philippine Wet Phosphoric Acid using D2EHPA-TOPO Solvent Extraction. Philippine Journal of Science 147(2), 275-284.

Ramasamy, V., Sundarrajan, M., Paramasivam, K., Meenakshisundaram, V., \& Suresh, G., 2013. Assessment of spatial distribution and radiological hazardous nature of radionuclides in high background radiation area, Kerala, India. Applied Radiation and Isotopes, 73, 21-31. https://doi.org/https://doi.org/10.1016/j.apradiso.2012.11.014

Ringnér, M., 2008. What is principal component analysis? Nature Biotechnology, 26(3), 303-304. 
https://doi.org/10.1038/nbt0308-303

Roscoe, R. J., Deddens, J. A., Salvan, A., \& Schnorr, T. M., 1995. Mortality among Navajo uranium miners. American Journal of Public Health, 85(4), 535-540. https://doi.org/10.2105/AJPH.85.4.535

Sambridge, M., Braun, J., \& McQueen, H., 1995. Geophysical parametrization and interpolation of irregular data using natural neighbours. Geophysical Journal International, 122(3), 837-857. https://doi.org/10.1111/j.1365-246X.1995.tb06841.x

Schipper, L. A., Sparling, G. P., Fisk, L. M., Dodd, M. B., Power, I. L., \& Littler, R. A., 2011. Rates of accumulation of cadmium and uranium in a New Zealand hill farm soil as a result of long-term use of phosphate fertilizer. Agriculture, Ecosystems \& Environment, 144(1), 95-101. https://doi.org/https://doi.org/10.1016/j.agee.2011.08.002

Sharma, D., Kamboj, S., Kamboj, S., Nair, A. B., \& Ali, J., 2010. Nuclear and radiological agents: Contamination and decontamination of human beings. International Journal of Pharmaceutical Sciences Review and Research, 5(3), 95-101.

Suggate, S. M., Cottam, M. A., Hall, R., Sevastjanova, I., Forster, M. A., White, L. T., Armstrong, R. A., Carter, A., \& Mojares, E., 2014. South China continental margin signature for sandstones and granites from Palawan, Philippines. Gondwana Research, 26(2), 699-718. https://doi.org/https://doi.org/10.1016/j.gr.2013.07.006

Sun, Y, Wu, B., Amelung, W., Christensen, B. T., Pätzold, S., Bauke, S. L., Schweitzer, K., Baumecker, M., \& Bol, R., 2020. Non-critical uranium accumulation in soils of German and Danish long-term $\begin{array}{llll}\text { fertilizer } & \text { experiments. } & \text { Geoderma, } & 370,\end{array}$ https://doi.org/https://doi.org/10.1016/j.geoderma.2020.114336

Sun, Yajie, Amelung, W., Gudmundsson, T., Wu, B., \& Bol, R., 2020. Critical accumulation of fertilizerderived uranium in Icelandic grassland Andosol. Environmental Sciences Europe, 32(1), 92. https://doi.org/10.1186/s12302-020-00367-w

Takeda, A., Tsukada, H., Takaku, Y., Hisamatsu, S., \& Nanzyo, M., 2006. Accumulation of uranium derived from long-term fertilizer applications in a cultivated Andisol. Science of The Total Environment, 367(2), 924-931. https://doi.org/https://doi.org/10.1016/j.scitotenv.2006.01.006

Taskin, H., Karavus, M., Ay, P., Topuzoglu, A., Hidiroglu, S., \& Karahan, G., 2009. Radionuclide concentrations in soil and lifetime cancer risk due to gamma radioactivity in Kirklareli, Turkey. Journal of Environmental Radioactivity, 100(1), 49-53. https://doi.org/https://doi.org/10.1016/j.jenvrad.2008.10.012

[UNSCEAR] United Nations Scientific Committee on the Effects of Atomic Radiation, 1986. Genetic and somatic effects of ionizing radiation. http://inis.iaea.org/search/search.aspx?orig_q=RN:18022637

[UNSCEAR] United Nations Scientific Committee on the Effects of Atomic Radiation, 2000. United Nations Scientific Committee on the Effect of Atomic Radiation. Sources and Effects of Ionizing Radiation.

Zhao, K.-D., Jiang, S.-Y., Ling, H.-F., Sun, T., Chen, W.-F., Chen, P.-R., \& Pu, W., 2016. Late Triassic Ubearing and barren granites in the Miao'ershan batholith, South China: Petrogenetic discrimination and exploration significance. Ore Geology Reviews, 77, 260-278. https://doi.org/https://doi.org/10.1016/j.oregeorev.2016.02.016 